\title{
Conservation of Creole livestock in the United States: challenges and solutions
}

\author{
Dan Phillip Sponenberg* $ه$ \\ Department of Biomedical Sciences and Pathobiology, Virginia-Maryland \\ College of Veterinary Medicine, Virginia Tech, Blacksburg, Virginia. USA.
}

\begin{abstract}
Conservation of Creole breeds in the USA provides for the survival of unique genetic resources that remain productive in challenging environments. Conservation is difficult because most creole breeds are local and have no formal organization of breeders. Successful conservation has depended on establishing accurate breed definitions and investigations of phenotype, history, and genetics in addition to accurate labelling and promotion of breed-specific as well as system-specific products. Organization of breeders and of breeding has been essential for the final success of conservation efforts. Each specific breed has met its own unique challenges. Among cattle breeds, Texas Longhorns needed an accurate breed definition as well as genetic investigations, whereas Florida Crackers needed organization. Spanish goats required definition, organization, and research into their productive potential. This has led to the Spanish goat now being secure as a popular choice for extensive production of goat meat. Navajo Churro sheep are maintained by ongoing phenotypic evaluation at each generation and careful attention to the frequency of phenotypic characteristics within the population. The other creole sheep breeds in the USA (Louisiana, Gulf Coast, and Florida) have benefitted from genetic studies that demonstrate differences among the breeds and guide conservation of each of these related types in isolation one from the others. The organization of creole swine has lagged behind the others, with the Duroc standing out as an exception that has become one of the main breeds in commercial hog production.
\end{abstract}

Keywords: livestock, breed conservation, genetic conservation

\section{Conservación de ganado criollo en Estados Unidos: Desafíos y soluciones}

Resumen. La conservación de las razas ganaderas criollas en los EE.UU. ha contribuido a la sobrevivencia de recursos zoogenéticos únicos que tienen buena producción en ambientes duros. La conservación es difícil porque la mayoría de estas razas son locales y no tienen una organización formal de los criadores. El éxito depende en una caracterización fija para la raza, e investigaciones del fenotipo, la historia, y la genética son muy recomendables. Organizar a los criadores y la cría ha sido esencial en el éxito final de estas razas. Cada raza enfrenta sus propios desafíos. Entre las razas bovinas la Texas Longhorn necesitó una definición precisa, así como investigaciones de su genética para asegurar niveles bajos de la introgresión de otras razas. La raza bovina Florida Cracker necesitó una organización de los criadores. La raza caprina Spanish requirió definición, organización, e investigaciones de las características productivas. Esta raza ya está segura por su papel en sistemas productivos en condiciones extensivas. La raza ovina Navajo Churro se mantiene por una evaluación fenotípica para todos los animales de todas las generaciones, y también por mantener la frecuencia de varias características fenotípicas de interés. Las otras razas criollas ovinas (Louisiana, Gulf Coast, and Florida) fueron documentadas como tres poblaciones distintas por investigaciones genéticas que demostraron diferencias entre ellas. La investigación ayuda a la conservación de las tres razas, una aisladas de las otras. La organización de los porcinos criollos no es muy avanzada. La raza Duroc es un tipo de criollo que ha llegado a tener un papel importante en la producción porcina comercial.

Palabras clave: ganado, conservación de razas, conservación genética 


\section{Introduction}

Several populations of creole livestock have survived in the USA, despite the centuries during which the original Spanish influence was largely replaced by English and German influences in culture, language, and genetic resources (Sponenberg, 2014). These Creole genetic resources of all species have survived at the periphery of agricultural systems. They have become endangered despite their high levels of environmental adaptation and good productive potential. Success in conserving them combines both scientific and political/cultural factors (FAO, 2013; Sponenberg, Martin, and Beranger, 2017). A protocol for conserving these valuable and unique genetic resources has worked well even in the face of genetic and cultural challenges (Sponenberg et al., 2019). This protocol depends on a three-tiered process based on the components of Discover, Secure, and Sustain. Each of these factors varies by species or specific population. Organizing local creole populations into recognized breeds is challenging, but several efforts have succeeded.

The Discovery process is complicated because the creole resources in the USA persist outside of the common agricultural systems. Usually the breeders are poorly organized and the animal population is poorly defined. Discovery includes definition of the population, and also by characterization through phenotype, history, and genetic tests. Discovery is often difficult because it is necessary to build trust among breeders and owners. In addition, the animals can be difficult to find because they are in remote situations. The goal is to include all of the available typical animals into the conservation program, while rejecting those with outside genetic influences.

Defining the population should emphasize the unique Iberian and African foundation of creole populations (Sponenberg and Quiroz, 2017; Ginja et al. 2019). Definition is followed by efforts at categorizing animals for inclusion into the conservation effort. Decisions on which animals to include can be done by three components: phenotypic examination, history of the population, and finally any genetic studies that are possible. The importance of each of these varies across species, and all three work well together in achieving final success.

Phenotypic examination involves an inspection of the breed type of candidate animals. This ideally involves linear measurements, but it has been equally useful to use a more subjective evaluation of animals that involves simpler visual inspection. This is especially true in situations where extensive production systems prevent capture and direct measurement of animals. The goal of phenotypic evaluation is to focus on typical creole phenotype and to exclude animals with evidence of introgression from other breeds. The phenotype of conservation interest varies depending on the species as well as on the breeds that were likely to have contaminated the original creole genetic resource. Most creole populations in the USA are adapted local breeds, and these tend to have more phenotypic variation than is typical of tightly standardized production breeds. Details such as color and presence of horns are usually a poor indicator of purity of breeding and should be allowed to vary widely. Beneath that variability is a consistent array of head, ear, and body conformation that indicates the creole origin of the animals.

Historical investigations are essential. The ideal history is long-term isolation of the animals. A population with a known or documented foundation is also useful, but this detail is often lost in the past and not available.

Genetic tests can involve autosomal microsatellites, whole-genome SNPs, mitonchondrial DNA, and the Y chromosome DNA. Each of these provides different information about the population, including foundation influences for each of these, but also for adaptive traits when whole-genomic data with medium to high coverage is available. Results can be compared to those of other creole populations as well as to foreign breeds suspected as being sources of introgression. In nearly all cases in the USA, genetic testing has been accomplished after historic and phenotypic evaluations. The results of the genetic investgations have validated the conclusions of the historic and phenotypic evaluations both for populations found to be fairly purely creole as well as those with introgression from other origins. The nongenetic approaches should therefore not be considered less valid than genetic tests even though they may be viewed as subjective instead of objective and scientific.

Securing the population involves assuring that the animals are safe and continue to be bred as a distinct genetic resource. This can involve removal to a new situation in some cases, but in most it involves organizing the breeders to focus on purebred breeding. Usually the breeders have a degree of pride in their livestock and are eager to participate once the resource is finally recognized as valuable and culturally relevant. 
Sustaining the population requires long-term strategies for breeding as well as for building demand for the breed and for its products. This can be accomplished by studies into productive potential and promotion of any unique characteristics.

The objectives of this paper are to describe the methods of conservation of Creole livestock breeds in the USA and to demonstrate the different ways that they succeed with different species and different breeds.

Candidate populations for conservation were presented to the Livestock Conservancy by breeders or agricultural officials. Populations were evaluated by criteria that reflected the location and general history of the area. The evaluations involved history, phenotype, and genetic studies. Strategies were then developed for long-term conservation of populations.

History and phenotype were often evaluated at the same time. The ideal history is one with a known foundation, but this is rare in most creole populations in the USA except to note that the animals are of local origin. The long history of creole populations in the USA has led to a loss of precise history, largely due to the replacement of the original Spanish-based culture.

Phenotype of candidate populations was assessed by a matrix of characteristics that focused on breed type rather than overall conformation (Sponenberg and Reed, 2015). For many populations the matrix centers on peculiarities of the conformation of the head, ears, and horns. The matrix is specific to each species and each candidate population, and emphasizes changes in phenotype that come from the breeds most likely to have been introduced into the area.

For many populations it was then possible to carry out genetic studies that compared the population to other available local breeds or to other creole breeds. In many cases the genetic studies validated phenotypic observations, and they also provided further information to guide conservation decisions.

Several different creole breeds have been successfully organized and conserved in the USA. Each of them has faced unique challenges in some aspect of the effort, and therefore each has a different lesson to teach about effective conservation of these valuable and unique genetic resources.

Several cattle breeds in the USA qualify as creole breeds (Ginja et al. 2019; Sponenberg, Davis, and Beranger 2018). The Texas Longhorn is the most famous of these. It has the advantage of serving as a focus of regional pride for Texans, so that recruiting breeders and maintaining herds is relatively easy. Initial attempts at conservation began in the 1920 s with government support. Both the relatively early start as well as the government interest have been rare for other creole breeds. Two government herds were developed specifically to conserve the Texas Longhorn, with animals selected by type and history. Only about seven private breeders kept the breed until the 1960s. Then the breed became more popular and many other breeders became involved. Selection began to favor color variation and extremely long horns. Bloodlines with introgression from other breeds predominated. In this situation breed definition became important.

A few breeders organized around the idea of conserving the original creole type, using a restrictive breed definition that excluded cattle with genetic influences from outside of the original Iberian and creole type. These efforts initially involved phenotypic and historic evaluation of candidate animals. This was originally followed by blood typing with antigens, which benefitted from several antigenic markers that cleanly separated creole and non-creole cattle. As bloodtyping became unavailable, the testing moved to microsatellite DNA testing, which in this breed proved to be somewhat less able to effectively discriminate between creole and non-creole influences. Finally, SNP technology is being used but the lack of background data on various breeds serves to make final designations more difficult than was the case with the earlier blood typing. This disadvantage will eventually be overcome, resulting in this technology being of great value in conserving this breed. The wisdom of the overall approach of first a phenotypic and historic evaluation has been validated by the genetic finding that the Texas Longhorn fits into the creole breed group (Ginja et al., 2019). Few cattle that are excluded by phenotypic evaluation end up passing the genetic test, and likewise few that are included phenotypically are rejected by genetic evaluation.

A second cattle breed, the Florida Cracker, benefitted from the involvement of the state government. The state has maintained breeding herds on state land and also helps in organizing breeders, events, and sales. These state herds were originally formed from a foundation of cattle selected from a very few sources on the basis of history and phenotype. Subsequent DNA studies have revealed a very strong representation of the creole foundation source (Ginja et al., 2019). The phenotype of these cattle varies some from the usual creole type, because the horns are more likely to angle up rather than laterally with a twist. 
This is due to specific selection by those responsible for the herds, who have long favored that type of horn. The result is that phenotypic evaluation needs to take into account local selection practices, because even within the creole group of breeds it is possible to change type by selection.

Today's Florida Cracker cattle descend from very few foundation influences, and a few of these survive outside of the herds owned by the state government of Florida. Most genetic studies have overlooked broad sampling of the privately owned herds, and hopefully this can be accomplished in the future to more fully characterize the breed.

Pineywoods cattle have also been considered as creole (Ginja et al., 2019). Herd histories involve genetic isolation of up to a century. The cattle generally have a creole phenotype, and the breed descends from several distinct old family bloodlines. The phenotypic and historic evidence pointed to a breed within the creole group. DNA testing has revealed only a small influence of the creole root, but equally establishes the Pineywoods as distinct from other breeds. This finding points to the need for conservation, but more as a local breed than as a true creole genetic resource.

Horse conservation in the USA faces many challenges, and this is especially true of creole horses (Sponenberg and Gómez, 2005). These are called various names including "mustang" and in some cases by specific family names of breeders. The name Colonial Spanish is often used as a general term for these horses. The phenotype of these is very distinct from the Thoroughbred, Arabian, draft, and coach horse influences that were the usual source of crossbreeding. These other breeds, especially the Thoroughbred and Arabian, have become the popular idea of horse type and beauty in the USA, so the creole type is not favored due to its smaller size and distinctive head conformation.

Colonial Spanish horses have persisted as small populations isolated one from another (Sponenberg and Gómez, 2005). The populations of most strains are too small for long-term avoidance of inbreeding depression. Because of regional and cultural histories of the strains, breeders tend to resist the idea of blending them together into a composite population, although this has advantages for long-term conservation of this genetic resource.

The validity of the approach of phenotypic and historic evaluation of these horses has been demonstrated repeatedly by DNA results (Sponenberg and Reed, 2015). Those populations with a history of isolation and with typical Iberian-derived conformation and type consistently group together or with other creole breeds from the Americas.

Donkey breeding in the USA, in contrast to horses, has only seen good organization in one breed: the American Mammoth Jack (Sponenberg, Beranger, and Martin, 2014). It is estimated that this breed is about $80 \%$ or more Spanish. The origin is from imports during the late 1700 s and the 1800 s rather than the early Spanish colonial imports that are typical of the other creole breeds of livestock. In contrast, feral burros of smaller size are common in several western areas, but their breeding has never been organized and detailed genetic studies have not been done. The history of these is vague, and the populations have been poorly investigated. They are thought to be all of mostly Iberian origin from early introductions because other colonial influences in the USA were from cultures rarely using donkeys.

The most numerous creole sheep breed in the USA is the Navajo-Churro which has long been an essential part of the culture of the Navajo indigenous nation and Hispanic families of New Mexico and Arizona (Sponenberg and Taylor, 2009; Taylor, Sponenberg, and Perezgrovas 2010). These sheep were the target of elimination from governmental programs that included slaughter as well as crossbreeding efforts to change the sheep to a finewool type away from the original double-fleece type that is more useful for traditional textile production.

Breeders have organized programs to identify and recognize these sheep. These work across all three cultures including Navajo, Hispanic, and Anglo. Sheep are accepted into a breed registry based on history of origin and phenotypic evaluation. Each sheep is accepted on its own phenotypic merit and no individual sheep is automatically included, even one with a long pedigree within the registry. This has preserved the original adapted, double coated breed.

Breeders have also been diligent to track the variation that is present in the breed, such as colors and the presence, absence, or number of horns. Results of the registration numbers of sheep with these characteristics are published every few years so that breeders can be alerted to any decrease in one of the variants and can then work to retain more of the sheep that have that variant. This prevents the extinction of variations within the breed. The breeders are diligent to use these registration trends to manage the various characteristics. 
Gulf Coast sheep are a local breed from the humid subtropical region in the Southeast of the USA (Taylor, Sponenberg, and Perezgrovas, 2010; Kijas et al., 2012; Blackburn et al., 2011). Their origin is uncertain, as is the relationship between those in Louisiana and the local flocks in Mississippi and Georgia. The definition of Gulf Coast Sheep, therefore, has never been firmly set. The breed type between the Louisiana sheep and the others is distinct. The Louisiana sheep tend to come from a single source flock and have tightly curled horns suggesting influence from Dorset sheep. DNA studies in which these Louisiana sheep were identified as "Gulf Coast," have revealed this connection to British breeds. The remaining Gulf Coast flocks with a more Iberian phenotype have yet to be sampled and compared. The local sheep from Florida have yet a third distinct type, and DNA analysis has documented that these are different than "Gulf Coast (Louisiana)" sheep (Kijas et al., 2012). This situation points to the complexity of organizing meaningful and effective conservation efforts. In this situation a breed definition is important, as well as clear historic, phenotypic, and genetic criteria for inclusion of animals and flocks into the organized conservation effort. All three of these genetic resources (Louisiana, Gulf Coast, and Florida) are well adapted to the region, with levels of parasite resistance that are important for successful sheep production in the Southeast USA.

Spanish Goat is the name that has long been used to refer to creole goats in the USA (Ginja et al. 2017, Sevane et al., 2019, Sponenberg and Edmundson, 2016). Unfortunately this name has had two meanings. One is a specific Iberian phenotype, the second refers to any crossbred goat. The breed has long been used for local meat production. Goat meat production became increasingly popular as a livestock business in the late 1900 s and early 2000s. Breeders imported Boer and Kiko goats to meet this need, and most goat breeders immediately assumed that the imported breeds were better and more productive than the local genetic resource which at that time was unorganized. Crossbreeding began and nearly absorbed the Spanish Goat. The breed remained purebred in the hands of breeders who were diligent to select for productive, adapted goats.

Spanish Goat breeders eventually began a loose organization, and goats were accepted on the basis of a phenotypic and historic evaluation. This phenotype occurs throughout the Americas, and also in Spain, but is not the only phenotype of Iberian goats. It is, however, the phenotype in the USA that is least likely to have introgression from Angora, Boer, Nubian, or Swiss breed dairy goats. This phenotype has a subconvex head profile, ears that are horizontal and carried forward, and long horns that twist. This phenotype has been validated as creole by DNA studies, with obvious relationships to other local breeds in the Americas (Ginja et al. 2017, Sevane et al., 2019).

The Spanish Goat was nearly lost because breeders assumed that the imported breeds had to be better than the local breed. Controlled studies have now revealed that the Spanish Goat is equal to, or better than, other breeds in terms of goat meat production (Browning and Leite-Browning, 2011, Browning, LeiteBrowning, and Byars, 2011). This is especially true if productivity is measured in terms of the inputs used. As is typical of local breed conservation, new candidate herds are still being evaluated and included in the conservation effort. Some of these have very low numbers, and breeding protocols are developed to assure broad recruitment into the breeding population so that genetic bottlenecks can be avoided.

Creole swine in the USA have experienced various fates. The Duroc is largely creole, and has emerged as one of the few breeds that form the cornerstone of industrial pork production not only in the USA but also internationally (Cortés et al. 2016). The Duroc stands out as an exception to the general rule that creole breeds of all livestock species in the USA persist only as isolated remnants of adapted but peripheral breeds.

Creole swine breeds in the USA include the Mulefoot, which shares the characteristic fused hoof with other breeds throughout the Americas (Cortés et al. 2016). The Mulefoot was briefly a mainstream agricultural breed in the early 1900s, but lost favor to other breeds because of its tendency to fatness as well as its black color. The Choctaw hog persists in very low numbers, with breeders only now organizing around hogs that are validated by phenotype and history. A few feral populations, such as on Mona Island, may represent early introductions of swine before the source populations in the Canary Islands were subject to introgression from Asian and European breeds, and are therefore a high priority for conservation (Olalde et al. 2015). 


\section{Discussion}

The creole breeds of the USA all have a similar history in their Iberian origin during the Spanish colonial period. In nearly every case this was later followed by nearly complete absorption through crossbreeding to later introductions of livestock from northern Europe as well as from India and South Africa (in the case of cattle and goats). The one notable exception is the Duroc hog, selected out of a creole base and now one of the pillars of international hog production. The Duroc demonstrates one argument in favor of conserving these creole genetic resources. Part of the reason the Duroc succeeds is the hybrid vigor following mating to other breeds of hogs, and this vigor depends on the relatively large genetic distance that can be expected from all creole breeds when compared to breeds from other geographic regions.

The status of creole breeds as local and overlooked genetic resources has long put them in special peril of loss through ignorance of their numerical status and relative purity of breeding. While the extensive and marginalized conditions under which they were formed has led to their exquisite environmental adaptation, it also serves as a real threat because they can be lost without much notice. In the modern situation the only way forward to assure conservation of the creole breeds of livestock is to define the breeds and then to organize breeders and conservation programs.

\section{Conclusions}

Conserving creole breeds of livestock is especially challenging in the USA for reasons that are both cultural/political as well as biological. The cultural challenges are the general lack of understanding that the Iberian influence was widespread and had long duration in the early colonial period. As a result, creole breeds in the USA do not cause much of a general sense of ownership or national patrimony. Even the official recognition of creole populations as breeds is poorly defined in the USA, leading to great confusion of the utility of breeds as defined genetic resources.

The biological challenges in conservation are difficult but can be overcome with adequate technical support and experience. Success has generally been achieved by adopting the approach of investigating history, phenotype, and genetics. A breed definition that reflects these investigations helps to provide the breed with an identity distinct from other breeds. This is true across species and breeds especially when combined with efforts to organize breeders. In breeds that are previously not organized it has been especially important to develop clear breed definitions. Assuring that the conservation effort is broad and inclusive of all qualifying animals has been important as a way to assure that the creole breeds can serve as productive genetic resources well into the future.

Conflict of interest. This research did not receive any specific grant from funding agencies in public, commercial, or not-for-profit sectors.

\section{Literature cited}

Blackburn, H.D, S.R. Paiva, S. Wildeus, W. Getz, D. Waldron, R. Stobart, D. Bixby, P.H. Purdy, C. Welsh, S. Spiller, M. Brown. 2011. Genetic structure and diversity among sheep breeds in the United States: Identification of the major gene pools. Journal of Animal Science. 89: 2336-2348.

Browning, R.; M.L. Leite-Browning. 2011. Birth to weaning kid traits from a complete diallel of Boer, Kiko, and Spanish meat goat breeds semiextensively managed on humid subtropical pasture. J. Anim. Sci. 89:2696-2707.

Browning, R.; Leite-Browning, M.L; Byars, M. 2011.vReproductive and health traits among Boer, Kiko, and Spanish meat goatts on humid, subtropical pasture conditions of the southeastern United States. J. Anim. Sci. 89:648-660.
Cortés, O., A.M. Martínez, J. Cañon, N. Sevane, L.T. Gama, C. Ginja, V. Landi, P. Zaragoza, N. Carolino, A. Vicente, P. Sponenberg, J.V. Delgado. 2016. Conservation priorities of Iberoamerican pig breeds and their ancestors based on microsatellite information. Heredity doi:10.1038/hdy.2016.21. pages 1-11.

FAO. 2013. In vivo Conservation of Animal Genetic Resources. FAO Animal Production and Health Guidelines. No 14. Rome (one of 5 contributors).

Ginja C., L.T. Gama, O. Cortés, I. Martin Burriel, J.L. Vega-Pla, C. Penedo, P. Sponenberg, J. Cañón, A. Sanz, A. Egito, L.A. Alvarez, G. Giovambattista, S. Agha, A. Rogberg-Muñoz, M.A. Lara, BioBovis Consortium, J.V. Delgado, and A. Martinez. 2019. The genetic ancestry of American Creole cattle inferred from uniparental and autosomal genetic markers. Scientific Reports 9:11486. https://doi.org/10.1038/s41598-019-47636-o . 
Ginja, Cl, L.T. Gama, A. Martínez, N. Sevane, I. MartínBurriel, M.R. Lanari, M.A. Revidatti, J.A. Aranguren-Méndez, D.O. Bedotti, M.N. Ribeiro, P. Sponenberg, L. Aguirre Riofrío, L.A. Álvarez-Franco, M.P.C. Menezes, E. Chacón, A. Galarza, N. GómezUrviola, O.R. Martínez-López, E.C. Pimenta-Filho, L.L. daRocha, A. Stemmer, V. Landi, J.V. DelgadoBermejo. 2017. Genetic diversity and patterns of population structure in Creole goats from the Americas. Animal Genetics doi: 10.1111/age.12529.

Kijas, J.W., J.E. Miller, T. Hadfield, R. McCulloch, E. García-Gámez, L. R. Porto Neto, N. Cockett. 2012. Tracking the Emergence of a New Breed Using 49,034 SNP in Sheep. PLoS One 7(7): e41508. doi:10.1371/journal.pone.0041508.

Sevane, N.. Cortés, O., L.T. Gama, A. Martínez, P. Zaragoza, M. Amills, D.O. Bedotti, C. Bruno de Sousa, J. Cañon, S. Dunner, C. Ginja, M.R. Lanari, V. Landi, D.P. Sponenberg, J.V. Delgado and the BioGoat Consortium. 2019. Dissection of the Iberian and African genetic contributions to Creole goat populations.

Animal doi:10.1017/S1751731117003627. 2018.Sponenberg, D.P. Local Goat Breeds in the United States. in Kukovics, S. Goats (Capra). INTECH OPEN. 2019. DOI: $10.5772 /$ intechopen.89213.

Sponenberg, D.P. 2014. Desafíos en la conservación de razas locales en los EEUU (Challenges in the conservation of landraces in the United States). Actas Iberoamericanas de Conservación Animal. 4: 181-182.

Sponenberg, D.P., J. Beranger, A.G. Martin. 2014. Introduction: Donkey Breeds and Genetic Management of their Populations. in: Navas González, F.J., Delgado Bermejo, J.V., Vargas Burgos, J.C. Current Donkey Production and Functionality: Relationship with Humans. UCO Press, Editorial Universidad de Córdoba. pages 1-38. 2017.Sponenberg, D.P. Cerdos Criollos en los Estados Unidos (Creole Pigs in the United States). Las Razas Porcinas Iberoamericanas. Un Enfoque Etnozootécnico. Editor, Olimpia Lima Silva Filha. Instituto Federal Baiano, Campus Valença. Salvador, Brazil. pages 83-91.
Sponenberg, D.P., D. Davis, J. Beranger. 2018. Bovinos Criollos de los Estados Unidos (Creole Cattle of the United States). in: Perezgrovas, R. Catálogo de los Bovinos Criollos de México: Razas Locales y Sistemas Empéricos de Manejo. Volumen XV Colección "Boca de Monte". Universidad Autónoma de Chiapas. San Cristóbal de las Casas.

Sponenberg, D.P., L. Edmundson. 2016. Razas Caprinas y Locales en Los Estados Unidos (Creole and Local Goat Breeds in the USA). Biodiversidad Caprina Iberoamericana. Edited by Vargas, JE, L Zaragoza, JV Delgado, L Rodríguez. University of Córdoba, Córdoba, Spain. pages 154-170.

Sponenberg, D.P., M.A. Gómez Jaramilla. 2005. La Conservación de los Caballos de Origen Español en los Estados Unidos (Conservation of Colonial Spanish Horses in the United States). Archivos de Zootecnía 206:171-175.

Sponenberg, D.P., A. Martin, J. Beranger. 2017. Managing Breeds for a Secure Future, Strategies for Breeders and Breed Associations. Second Edition. 5M Publishing. Sheffield, UK. 288 pages.

Sponenberg, D.P., A. Martin, C. Couch, J. Beranger 2019. Conservation Strategies for Local Breed Diversity. Diversity 2019, 11, 177: doi: 10.3390/d11100177. impact factor 2.047 .

Sponenberg, D.P., J. Quiroz. 2017. Definición de Razas Locales Primer Paso en su Conservación (Definition of Local Breeds the First Step in their Conservation) Actas Iberoamericanas de Conservación Animal. 10: 74-77.

Sponenberg, D.P., C. Reed. 2015. Uso de Matrices Fenotípicos en la Conservación de Razas Locales. Actas Iberoamericanas de Conservación Animal. 6: $67-73$.

Sponenberg, D.P., C. Taylor. Navajo-Churro. 2009. Sheep and Wool in the USA. Animal Genetic Resources Information. 45:99-106.

Taylor, C, D.P. Sponenberg, R. Perezgrovas. 2010. Razas Criollas Ovinas en los Estados Unidos. Biodiversidad Ovino Iberoamericano pages 447-462. Servicio de Publicaciones, Universidad de Córdoba. 